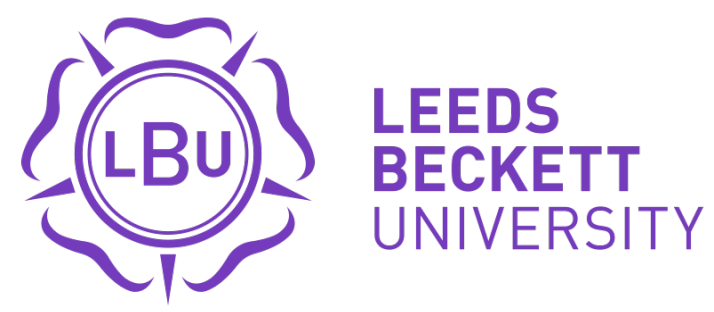

Citation:

Minocha, S and Hristov, D and Reynolds, M (2017) From graduate employability to employment: policy and practice in UK higher education. International Journal of Training and Development, 21 (3). pp. 235-248. ISSN 1360-3736 DOI: https://doi.org/10.1111/ijtd.12105

Link to Leeds Beckett Repository record:

https://eprints.leedsbeckett.ac.uk/id/eprint/4375/

Document Version:

Article (Accepted Version)

The aim of the Leeds Beckett Repository is to provide open access to our research, as required by funder policies and permitted by publishers and copyright law.

The Leeds Beckett repository holds a wide range of publications, each of which has been checked for copyright and the relevant embargo period has been applied by the Research Services team.

We operate on a standard take-down policy. If you are the author or publisher of an output and you would like it removed from the repository, please contact us and we will investigate on a case-by-case basis.

Each thesis in the repository has been cleared where necessary by the author for third party copyright. If you would like a thesis to be removed from the repository or believe there is an issue with copyright, please contact us on openaccess@leedsbeckett.ac.uk and we will investigate on a case-by-case basis. 


\title{
From Graduate Employability to Employment: Policy and Practice in UK Higher Education
}

\begin{abstract}
The purpose of this paper is to enrich the current conceptualisation of graduate employability and employment through the lens of policy, academia and practice in UK Higher Education (HE). We examine the UK policy context that is shaping graduate employability and employment debates before enriching this conceptualisation through a discussion of key themes in the academic literature. We then undertake a comparative study across a sample of 35 Higher Education Institutions (HEIs) in the UK to identify and discuss key employability practice areas shaping their graduate employability and employment provision. We do so by drawing on institutional employability data that is already available in the public domain. In mapping key themes in the literature against institutional employability practice, we conclude that the employer-university interaction theme in the literature is not sufficiently addressed in UK HE practice. Drawing on the evidence from our comparative study, we provide a discussion on four directions worthy of further exploration by universities as they shape their institutional responses to the lack of employer-university interaction.
\end{abstract}

Keywords: graduate employability, graduate employment, employer engagement, employability skills, Higher Education, university - employer interaction 


\section{Introduction}

The overarching purpose of this paper is to enrich the current conceptualisation and understanding of graduate employability and employment through the lens of policy, academia and practice in UK HE. We do so by drawing on institutional employability data that is freely available in the public domain, such as university webpages and relevant digital media. While the discourse on graduate employability is gaining international prominence, arguably, the particular dynamics of the UK HE sector, e.g. increased competition among HEls, emphasis on student experience and gain, merit specific attention (Mina and Probert, 2012) and we begin our paper by examining the UK policy context that is shaping the current practice.

We then go onto the academic critique on graduate employability and employment has grown exponentially, where key themes include: factors driving employability (Miller, Biggart and Newton, 2013); development of employability enhancement strategies and tools (Haasler, 2013); the mismatch between the demand and supply of employability skills (Agrawal, 2013); and greater openness in collaboration between employers and the Higher Education (HE) sector (Mina and Probert, 2012). This fragmented nature of the literature prompts further conceptualisation of graduate employability and employment, which is attempted through a discussion the key strands in the literature base.

Within this context, we strengthen the current understanding of practice related to graduate employability and employment across the UK HE sector by examining a range of institutional initiatives of UK universities in the domain of graduate employability and employment through a comparative study drawing on data that is already available in the public domain (after Pool, Qualter and Sewell, 2014).

Evidence of good practice however presents opportunities to provide directions to inform graduate employability practice across the UK HE sector. Based on outcomes of our comparative study, we offer key avenues for the development of UK HE practice and policy surrounding graduate employability and employment with a particular focus on employer-university interaction. These are aimed at institutions, which are in the process of reshaping their own institutional practice in relation to employer-university interaction. We conclude the paper with a short discussion of study limitations, implications to policy and practice and avenues for future research in this area.

\section{The Policy Context}

With some 2.5 million registered students (Universities UK, 2013b), the UK HE sector has a key role in contributing to the growth of the national economy and enhancing the productivity of the workforce. Not surprisingly, nurturing the capability of $\mathrm{HE}$ to develop work ready graduates has become central to UK Government 
policy agenda (Bryson, 2013; Universities UK, 2013a). The recent Government White Paper 'Success as a Knowledge Economy' (May 2016) restates the case for the role of universities as engines of innovation and growth.

UK universities are under increased pressure to develop employable graduates (Brown, 2014) and demonstrate this through institutional employability data. The number of graduates in the UK labour market has seen a steady increase, where they accounted for 12 million of UK's total workforce (Office for National Statistics, 2013). According to HESA (2014), the total number of HE qualifications obtained in $2012 / 13$ by full time, first degree UK domiciled graduates, was 303,510 and yet the proportion of recent university leavers who have taken non-graduate jobs has risen to $47 \%$ (Office for National Statistics, 2013). This may indicate that there are simply not enough graduate level jobs for the number of graduates entering the workforce every year. However, a recent report highlights the proportion of jobs requiring a $\mathrm{HE}$ degree on a national level has grown to 26\% in 2012 (Felstead et al., 2013).

Universities are taking increased responsibility for helping their graduates in their efforts to secure a job (Docherty, 2013), particularly in light of recent trends of graduates engaging in non-graduate roles (Office for National Statistics, 2013). The impact of universities in this area is open for debate (Mina and Probert, 2012) given the on-going commitment to the 'massification' of UK HE and coupled with the impact of the recession on graduates willing to engage in non-graduate roles.

The limited data available suggests two aspects to the problem. There are too few graduate level jobs offered by organisations relative to the number of graduates coming out of universities in each year - perhaps to the extent of around 142,000 annually (using HESA and ONS data). Also universities are becoming increasingly competitive on graduate employability and are pursuing strategies to increase their share of the graduate employment market.

Analysing the balance between the supply of graduates by UK universities and the demand for graduates by the full range of businesses and organisations ought to be relatively straight forward. We have easily available data on the number of graduates from UK universities each year though we do need to make adjustment for the number of international students, who return to their home country to seek work. Equally, there is a trend towards international graduates entering the UK job market each year, particularly for globally profiled companies in key locations such as London. UK universities need to adjust their policies and practice to take account of the global market for graduate talent, where one approach to addressing this opportunity is the fusion of two strategically-important institutional agendas, namely employability and internationalisation (Bothwell, 2016).

The data challenge relates to the demand side of the market and we need to be creative in our use of different data sets for helping understand the nature of the demand for graduates by companies and organisations. Not all these data sets are 
directly comparable and joining up the different statistics is fraught with data compatibility problems. For example, the First Destination Survey gives us a reasonable first take on the range of different jobs and different types of organisations students may end up working in the first 6 months; the Association of Graduate Recruiters (AGR) is able to provide data relating to member companies of the AGR but necessarily this is limited to larger graduate recruitment companies.

In summary, it is not possible to rigorously assess whether there is a theoretical balance of demand and supply in the graduate employment market. While large business graduate recruitment activity can be studied, small business data is lacking and thus missing the full picture. The HESA/ONS date referred to above suggests some 142,000 graduates may not have the skills and experience mix on their CV to secure a graduate level job.

It is understandable that the area of graduate employability and employment has become a priority for employers, government and universities. It is intuitively obvious that there is a role for closer university-employer interaction even given the limited data available to assess and measure demand-supply balance. Equally, graduate employability definitions are also problematic. Conceptualisation of graduate employability through a review of key literature contributions in this domain can assist with developing a sophisticated understanding of this data and broadening graduate employability definitions.

\section{Graduate Employability, Employment and HEls}

The subject of graduate employability has become a notion that is a key subject of debate in the UK HE (Maxwell et al., 2009; Rae, 2008). There are two aspects that are particularly helpful in making sense of the literature. The first relates to employability as 'job getting' - the ability of the graduate to secure a job after graduation (Harvey and Knight, 2003); the second aspect relates to the development of attributes, qualities and skills considered essential to employers and that help graduates secure a graduate job (Yorke, 2004). The Higher Education Academy (HEA) provides a more graduate-centric interpretation of employability with employment seen as a graduate outcome where graduate employability is based on two distinctive approaches (Pegg et al., 2012). The first relates to what can be measured and used in information that is published by universities; the second sees graduate employability as embedded in pedagogy through developing a wide array of knowledge, skills and attributes to enhance career prospects of graduates (Pegg et al., 2012). The concept of graduate employability may have been relatively well defined, but the extent to which graduate employability is being effectively addressed by UK HEls is an area of on-going debate (Tomlinson, 2007; Wilson, 2012).

We used existing comprehensive reviews of contributions to the literature of graduate employability as the basis of drawing up our thematic analysis. We 
examined articles featured in three key reviews of graduate employability literature, namely Lees (2002), Tomlinson (2012) and Bowers-Brown and Harvey (2004). Drawing on the extant graduate employability literature discussed across these three reviews, we arrived at five themes, which have been identified as key by the above three reviews:

I. Employability as core purpose of HE (identified as a key theme by Holmes, 2013);

II. Graduate skills (generic versus technical) (see Lambert, 2003);

III. Curriculum and pedagogy for employability (see Butcher et al., 2011);

IV. Measuring success of graduate employability practices (see Stott, Zaitseva and Cui, 2012); and

V. The interaction between employers and academia (see Argawal, 2013).

We discuss key literature themes that define the graduate employability landscape with the view to provide a richer and wider conceptualisation of this agenda in UK HE.

\subsection{Employability as a core purpose of HE}

Graduate employability is high on the agenda for UK HE and many universities have been engaged with the notion of embedding employability and employability-related skills in courses and programmes (Yorke, 2004). Key UK Government reports on HE have also emphasised the role of universities in addressing graduate employability (see Browne, 2010; Dearing, 1997; Leitch, 2006). Arguably, the reasons for intensifying discussions on the notion of graduate employability have been twofold: firstly, government concerns about graduate employability and its significance to economic growth; and secondly, employers highlighting the importance of developing graduate skills and experience (Harvey and Knight, 2003). Inevitably this raises the argument that in an era of fast growing knowledge economies and globalisation, a core purpose of $\mathrm{HE}$ education is to prepare graduates that are work ready (Hesketh, 2003; Purcel et al., 2008; Rae, 2008). A quite different message dominated the 1960-1980's where the emphasis was upon university being a life experience and the traditional notion of reading for your degree to acquire knowledge and wisdom.

Another aspect of employability as a core purpose of $\mathrm{HE}$ lies with students themselves. Some students may be more employable than others, particularly if they have work experience prior to university thus making them more work-ready graduates. Equally, academic subjects and degree courses can differ significantly in their potential employability outcomes. It is undoubtedly the case that the UK government, employers and students have a strong sense of common purpose as to how universities should be focusing their courses and research on making a contribution to graduate employability. 


\subsection{Graduate skills (generic versus technical)}

The second key theme in the literature, graduate skills, refers to the range of qualities and characteristics that employers look for to recruit and support career progression and lifelong learning (Miller, Biggart and Newton, 2013). This points to an important challenge many universities face - the shifts in graduate employability towards a demand-driven as opposed to the more conventional supply-led approach (Leitch, 2006).

Employability skills have often been labelled as generic in nature - combining socalled 'basic functional skills' with personal skills and qualities (Haasler, 2013). Reports by Dearing (1997) and Browne (2010) both emphasised that universities are not producing the right mix of skills to meet employer needs. There is a generic versus technical skills debate in terms of their significance to employability (Morrison, 2014). The 2011 Confederation of Business Industries (CBI) Education and Skills Survey pointed out that $82 \%$ of employers rated generic employability skills as a key graduate recruitment factor whereas $68 \%$ valued degree-specific skills (CBI, 2011). This suggests a paradox where employability skills may be degree-tailored for some graduates whilst more generic skills may be more relevant to the employability of others.

The BIS (2011) concluded that whatever definition of employability skills is put in place, there is a need to ensure that this definition is aligned with employer expectations. It is clear in recent years that employers have increasingly engaged with offering specifications of demand-driven workplace skills (Brown, 2014; Bryson, 2013) and this is feeding through to new curricular and pedagogic approaches for addressing graduate employability, e.g. Degree Apprenticeships in the UK.

\subsection{Theme III: Curriculum and pedagogy for employability}

There has been an on-going commitment of universities to integrate themes relating to employability across curricula and pedagogy. Current approaches to enhancing employability in HE involve a mix of various on-campus modules and employerdriven experience together with reflective, self-assessment tools to examine the employment readiness of students (Armsby and Costley, 2010; Andrews and Russell, 2012). A blending of curricular and extra-curricular approaches to supporting the delivery of increased graduate employability by addressing disparities between student perceptions of employability and those of employers is also a key theme (Tibby, 2012).

Yorke and Knight (2006:14) contended that the full spectrum of pathways to embedding employability in the curriculum features a number of overlapping approaches, among these: 
- embedding employability in the core curriculum;

○ using work-based curriculum components;

- adopting employability-related modules;

○ work-based learning in parallel with curriculum (Yorke and Knight, 2006).

Although the first three are believed to have the greatest potential for enhancing employability, Yorke and Knight (2006) argued that the last two would be the most practical. A more inclusive set of employability models and approaches may not always be developed within the core curriculum (Andrews and Russell, 2012) but it has been argued that extra-curricular activities to nurture graduate employability should be further recognised by HE institutions Tobin (2010). Despite an increasing large number of curricular and pedagogic developments to address graduate employability, the extent to which these have been embedded across the sector is unknown (Lowden et al., 2011) and so is the impact of these developments on both employers and academia.

\subsection{Measuring success of graduate employability practices}

Employability as a concept may be well-developed but there are debates as to how to measure outcomes of employability initiatives in universities (Pool, Qualter and Sewell, 2014). It has been argued that few universities evaluate the actual impact of their graduate employability practices and measuring the effect of employability support therefore remains a challenge (Tibby, 2012). Harvey et al. (2002) highlighted that existing employability performance indicators are inadequate in terms of measuring the impact and benefits of policies and practices in universities. The percentage of graduates in the population of the UK has risen from $17 \%$ in 1992 to 39\% in 2013 (Office for National Statistics, 2013). Inevitably graduate employability has become an issue and is often linked with the local development agenda (Witty, 2013). The question of whether current approaches to developing graduate employability by universities are effective remains an unanswered and complex question (Cranmer, 2006).

\subsection{Interaction between employers and academia}

An increasing body of evidence suggests that employer engagement initiatives may be able to provide substantial benefits to both individuals and employers (Maxwell et al., 2009). As a result, universities are now regularly making explicit in their student recruitment the portfolio of employability deliverables they are offering (Andrews and Russell, 2012). Collaboration between universities and employers is seen as a top priority for developing employer-led employability initiatives and these take many different forms including guest speakers, workshops delivered by employers, work 
placements, and consultancy projects (Armsby and Costley, 2000). University interaction with employers is seen as key to providing graduates with hands-on experience through internships and placements (Lester and Costley, 2010). However, there remain many issues and barriers to successful university-employer interaction.

We build on the challenging data surrounding graduate employment statistics highlighted in our policy section and our conceptualisation of graduate employability and employment by deepening the current understanding of practice related to this concept across the UK HE sector through a comparative study.

\section{Methodology}

Our knowledge of practice is informed by a comparative study across a sample of universities to examine current institutional approaches to addressing the graduate employability-to-employment gap. The underpinning research draws on a diverse sample of 35 UK universities representing both older 'red brick' as well as post-1992 HE institutions (Table 1) using a purposive sampling approach (Tongco, 2007). One purpose of which is the inclusion of a diverse sample of institutions; and institutions with strong employability presence in the public domain.

The diverse nature of the sample involved the top five new universities with highest ranking in the 2013 employability assessment (HESA, 2013) in addition to 19 former polytechnics and other post-1992 HEls. The sample included 11 'red brick' HEl's, of which six were Russell Group institutions.

Table 1. Sample

\begin{tabular}{cccc}
\hline \multicolumn{4}{c}{ 35 UK HEls } \\
\hline \multicolumn{2}{c}{11 Old Universities } & \multicolumn{2}{c}{ 24 New Universities } \\
Russell Group & Other Red Brick & Top Employability & Other Post-92 \\
6 & 5 & 5 & 19 \\
\hline
\end{tabular}

The strong employability presence dimension of the sample draws on institutional data that is already available in the public domain. For the purpose of this research we defined the public domain as an open data domain of digital content. This included an investigation into graduate employability offering published on institutional websites and other digital media for each of the selected 35 universities. The size of our sample was largely defined by the available institutional employability data and provision of employability practice of UK universities in the public domain. Universities with a strong employability presence in the public domain were thus considered for inclusion in the study. 
Further, thematic content analysis (Boyatzis, 1998) was then carried out across other publicly available secondary data in the form of case studies, HE sector statistics, institutional employability reports and statements, working papers and academic articles.

\section{Current institutional practice in graduate employability in UK HE}

Through our sample of HE institutions, in this section we provide a discussion of identified key employability practice areas across the chosen sample; areas, which define the graduate employability offer at these institutions:

Skills Set Development: Findings suggested that over half of the sampled institutions (54\%) delivered skills development programmes centred around employability. Employability skill development initiatives featured short courses, workshops, events and seminars, coaching and mentoring, mock assessments and training centres. Examples are the University of Chester's Enhance Your Employability programme with its focus on developing employability skills through series of workshops and seminars; a number of 'red brick' HEls implemented some distinctive initiatives to address employability when supporting skills development of graduates. Examples are Newcastle's Graduate Skills Framework preparing graduates for learning, life and work in a global economy.

Personal and Professional Development (PPD): This is a common employability practice area and is concerned with initiatives aimed at creating students' career or professional trajectory (James, 2008). PPD opportunities were delivered across all sampled universities and featured an extensive list of modules in a wide array of subject disciplines. The University of Huddersfield, for instance have introduced 29 different PPD courses. The top five institutions for employability nevertheless dominated in the provision of PPD initiatives. Examples include the Robert Gordon University, which delivers a wide range of accredited PPD courses in the areas of law, business, public policy, media and communications.

Professional Accreditation: Accreditation of university courses by professional bodies is also used as a tangible way of demonstrating student employability skills (BIS, 2011). This employability practice area was found in $89 \%$ of the samples HEls. Russell Group universities were notable for championing a range of officially recognised courses and units. Examples were Exeter and Nottingham, where UK and European professional bodies have accredited full-time and short courses in accountancy, management and business. The top five for employability HEls, on the other hand, delivered a limited number of accredited programmes, courses and units in the areas of management and marketing, health, engineering and IT technologies. Other post-1992 universities, in contrast, offered accredited programmes in a wide spectrum of subject disciplines. 
Careers Services and Support: This employability practice area relates to the provision of extensive employability support including job search opportunities, interview and assessment preparation. This area was consistent with $100 \%$ of the sampled HEls having some form of careers unit or service assisting students and graduates. Most units also provided career planning, support and advice, with examples being University of Surrey where students undertake a Before You Go week with focus on practical workshops and employer guest lectures. Such units have, however, been viewed as being inefficient and providing only limited activities for the number of students they have to deal with (Harvey and Knight, 2003).

Internship and Placement Opportunities: This employability practice area involves the provision of a range of short to long-term internships and placements, with local SMEs, MSBs and 'blue chip' companies. Opportunities for students to undertake internships, both on campus and with employers, were provided by all sampled HEls. Findings suggested that widening participation in such activities was an issue as universities often offered only a small number of internships to students. Oxford Brookes, for instance provided a total of 20 placements on their graduate trainee internship scheme, whilst Strathclyde provided 30 research and summer internship placements. Similar was the case with Russell Group institutions.

Enterprise Support: This is another key employability practice area amongst UK HEls. Enterprise support was available to students and graduates across $94 \%$ of the sampled HEls. Some institutions used this opportunity to engage with local SMEs and business networks in the co-delivery of research projects, such as at University of Greenwich and Nottingham University. Start-up support for students and graduates was provided by $51 \%$ of the sampled universities, where old universities outperformed post-1992 ones by delivering distinctive enterprise schemes, such as The Elevator Scheme at Newcastle University. Examples from post-1992 HEls included initiatives, such as Activ8 Your Business at the University of Huddersfield.

Volunteering and Community Engagement Opportunities: This area was present across all sampled HEls and typically involved students working on a range of community and environmental projects, where some projects were student-led and offering certification (e.g. University of Lincoln). The impact of university-led volunteering and community engagement initiatives were particularly notable in areas such as social enterprise. Russell Group and other 'red brick' institutions provided a range of volunteering opportunities such as graduate and student-led community projects (Nottingham University), international outreach (Leicester and Exeter), and even volunteering online (Aston University).

Following a discussion of each of the seven employability practice areas characterising the graduate employability offering at sampled universities, we map these against the five themes in the literature review in order to provide a visualisation of the extent to which these key themes in the literature are addressed 
by the identified seven institutional employability practice areas (see the second column on Figure 1).

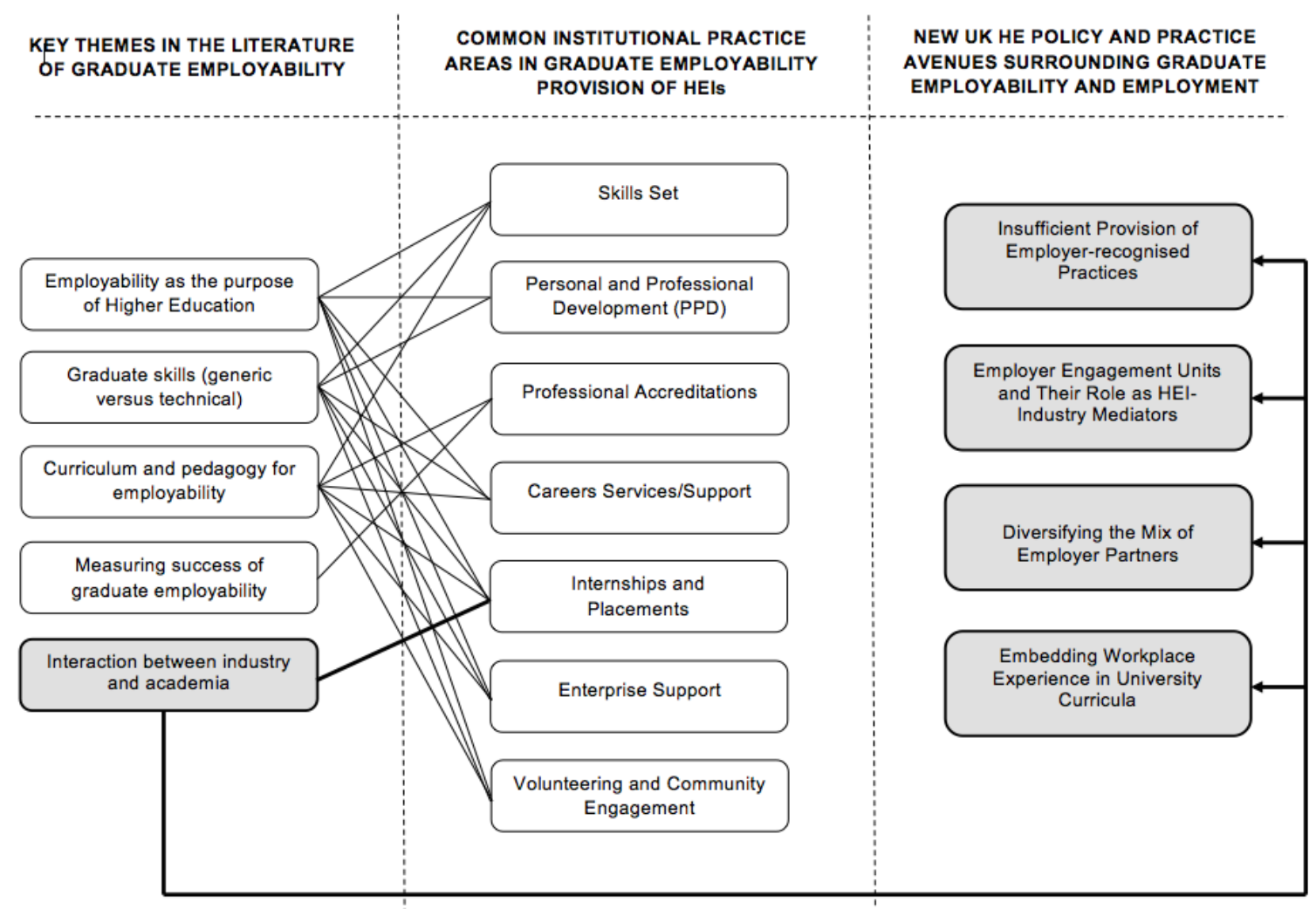

\section{Figure 1 Literature themes and HEI Response Map}

Our findings are reflected in Figure 1, which suggests that identified areas of institutional practice in graduate employability are predominantly related to the first four literature review themes. This relation is evidenced on Figure 1, where a high density of links between the first four literature themes and practice areas is evident. Links correspond to the number of ways in which literature themes are translated into institutional employability practices. Examples are the Graduate Skills and Curriculum and pedagogy themes, which have been well covered across the sampled HEls.

The fifth literature theme, namely 'Interaction between industry and academia' is linked to only one practice area - that of internships and placements. This suggests less emphasis on developing work/action/practice-based learning through employeruniversity interaction, when compared to skills developed in house such as PPD opportunities and campus careers support. Further, only $9 \%$ of the sampled institutions provide examples of close interaction with employers through the internships and placements route.

In response, we thus offer four avenues for new UK HE policy and practice surrounding the graduate employability agenda, particularly in light of employeruniversity interaction. These are discussed below. 


\section{New UK HE policy and practice avenues surrounding graduate employability}

Through an analysis of our findings across the sampled HEls (and after Wilson, 2012) we are able to identify the limited interaction between employers and academia as a key factor that define the graduate employability landscape in UK HE. Within this context, we offer some avenues for new UK HE policy and practice surrounding graduate employability, particularly in the area of strengthening employer-university interaction. These avenues may prove beneficial for UK HE policy in improving graduate employability figures, but also for institutions as they shape their own institutional responses to the lack of employer-university interaction.

\subsection{Employer-recognised initiatives}

The evidence base suggests a lack of reference to real world experience, where institutions deliver courses that are recognised, supported, and jointly-led by employers. Many external bodies are able to provide extensive support on graduate employability and help students and graduates cope with the challenges of the workplace (CBI, 2009). However, the extent to which HE institutions understand and make use of this expertise is still unclear.

Employer recognition of collaborative initiatives among universities and employers are generally aimed at bridging the gap between institutional curriculum and employer expectations through partnerships in the delivery of practice-oriented curricula, provision of company placements with focus on enhancing student employability, employer-approved courses and related employer-recognised initiatives. Our findings revealed that just over $9 \%$ of our studied sample delivered employability initiatives which are endorsed by employers. This supports our earlier argument (under Theme I of the literature review) that employer input into institutional curriculum at present is marginal, particularly in the area of practice and work-based learning accreditation and clearly more strategic involvement from both sectors is needed. Such involvement can feature the development of institutional employability initiatives that are endorsed by employers, which is supported by our findings.

\subsection{Employer Engagement Units and their role as HEl-employer mediators}

Employer engagement units are another avenue surrounding the graduate employability landscape. Units can facilitate closer university-employer interaction and improvement of graduate employability figures. This approach to employer engagement was undertaken by $11 \%$ of the sampled HE institutions. Even though Wilson (2012) argued that employer engagement has become common within the 
academic culture of the former polytechnics, our comparative study suggests that the majority of sampled post-1992 institutions have not sufficiently explored the opportunities to engage with employers more fully. Often employer engagement units are located in careers services units within universities.

Looking back to our discussion of the characteristics of HE employability provision we identified the issue of consistency of careers functions across the sample, noting that these university structures lag behind in demonstrating a holistic approach to graduate employability, particularly in employer engagement through the provision of input into curriculum content and the delivery of practice-led pedagogic models. Maximising graduate employability opportunities is a function of connecting demand and supply and this should be done in a more strategic fashion.

\subsection{Diversifying the mix of employer partners}

Our comparative study revealed that sampled universities have established links with predominantly 'blue-chip' employers, where SMEs and medium-sized employers have been involved in university-industry partnerships to a lesser degree. This stance is supported in an Edge Foundation study, which suggests that the majority of links universities have established are with a fewer large companies rather than SMEs (Lowden et al., 2011). We too concluded (after Witty, 2013) that smaller companies are particularly overlooked by universities, despite that they may serve an important role in university-employer interaction. The recently announced Small Business Charter initiative launched by the 2010 coalition government in partnership with the Chartered Association of Business Schools (CABS) has taken this challenge head on. With SMEs responsible for employing 24.3 million people in the UK it is SMEs that may well have a transformative effect on creating further graduate-level employment opportunities to recent graduates.

\subsection{Embedding workplace experience in university curricula}

Workplace experience that is embedded in university curricula is another key development in graduate employability which warrants further attention and depends largely on whether universities are able to engage with employers effectively. Our findings suggest that the practice in universities is a mixed and varied economy in terms of their implementation of the 'graduate employability' model.

Whilst the majority of sampled institutions delivered extensive extra-curricular employability opportunities, the spread of employability initiatives and processes of industry engagement were less evidenced, particularly at the curriculum level. This is despite findings of a study commissioned by the Department for Business, 
Innovation and Skills, which revealed that $69 \%$ of UK universities had a strategy for enhancing employability prospects of graduates (BIS, 2011). Insights provided by the comparative study therefore debate the extent, to which such strategies have been tailored to respond to the needs of both graduates and employers.

\section{Conclusion}

The overarching purpose of this paper was to enrich the current conceptualisation of graduate employability and employment in UK HE through policy, academic and practice perspectives as the basis of addressing the graduate employability-toemployment gap in UK HE. Our secondary research and review of current practice provides the basis for future research. With university-employer interaction as the contextual factor, our research evidences further opportunities to understand the notion of graduate employability, but also to address the challenging data surrounding graduate employment statistics highlighted in our policy section. In light of this, we provided a discussion on new UK HE policy and practice avenues surrounding graduate employability.

This paper is premised on the view that universities in general have a key role to play in the growth and development of the UK as an economy and as a knowledge based society. Global competition between nations is sharpening the edge to which universities need to perform as a 'supply pipeline' of graduate level talent to employers and industry. While some universities may retain more traditional academic missions as their core purpose, the majority of universities will not be able to and the UK government not unreasonably is expecting universities to respond to this agenda as the global knowledge economy increases competition. It is clear that many universities can therefore adopt good practice aimed at enhancing the employability of their graduates. This is indeed now happening and this paper provided a snapshot of some key developments in universities surrounding the graduate employability agenda.

Interpreting the available data on graduate employability is not without problems. However, universities are increasingly being judged in terms of their performance on this data. At the most basic level the data on graduate employability suggests there are more graduates, perhaps as many as $30 \%$ more, exiting universities than UK businesses and organisations seek to recruit in any year. This in itself unlocks increased competition for graduate level jobs. Clearly, we would like to see an increase in the number of graduate level jobs. However, as our policy context discussion suggested as many as a half of all graduates (142,000 graduates) are in non-graduate jobs. This suggests skills mismatches and also the kind of skills deficits regularly reported by key graduate recruiters in the UK, e.g. Hays and their Global Skills Index. 
The position this paper takes is that it is reasonable that all Universities should be working towards policies and practices that will ensure that all their graduates have the opportunity to acquire and develop workplace skills and work experience as part of their degree programme. In sum, the base line is to aim that all graduates should have the chance to compete for a graduate level job in the UK and internationally. However, we accept the reality that there may well be more graduates than the available graduate level jobs and this will in any event be impacted by local economic as well as global economic conditions. Investing in 'graduate level' education beyond a target level of graduate-level jobs is an aspiration that is justified in terms of offering educational opportunity to all and for the long term well-being of the UK's economy and society.

\section{Implications for other HEls and HE policy}

Research findings prove to be of practical importance to other HEls in three key areas. First, while most enquiry in the graduate employability domain is still concerned with debates surrounding skill development and assessment tools, the success of HE institutions in graduate employability lies in facilitating a closer dialogue between students and employers with the aim to provide more graduatelevel opportunities.

Secondly, our data makes a call for greater university-employer interaction and the adoption of proactive institutional approaches as the basis of improving graduate employment figures. This call becomes further cemented through the outcomes of our analysis of institutional data and the four directions we provide to guide universities as they shape their own institutional response to the lack of employeruniversity interaction.

Thirdly, at policy level, the incentivisation for greater university-employer interaction would be key to improving institutional response to the graduate unemployment agenda. Focused specifically on SMEs, such incentivisation could achieve greater impact. The recently established National Centre for Universities and Businesses (NCUB) provides a policy response to the lack of employer-university interaction. However, more evidence of involving a diverse set of industry partners is welcomed.

\section{Limitations and future research}

As this paper draws on institutional employability data that is already available in the public domain, the underpinning approach implies the use of data of a 'self-reported' nature. Such data arguably provides a one-dimensional picture. Hence, primary data on institutional employability policy and practice implementation has not been considered for inclusion and is a contender for future research. Further, we acknowledge the fact that the studied $21 \%$ of all UK HEls do not provide a sample 
that is statistically representative of the UK HE sector due to limited data in the public domain on institutional employability practice for the remaining $79 \%$ of UK universities. The size of our sample was therefore largely defined by the available institutional employability data and practice in the public domain.

Future research should look to include all 163 UK HE institutions. One which is grounded in empirical data would use the above insights as a starting point for a more rigorous examination of the terms, practices and outcomes of employability initiatives and demystify the complex landscape of graduate employability in UK HE. Equally there is a need for in-depth case studies so that experiences of other institutions on a journey to place employability at the heart of their vision, mission and actions are highlighted. They can be seen as a valuable resource to shaping improvements in this area as a sector as is this paper, which gives evidence-based call for stronger, deeper, wider university-employer interaction as the basis of creating graduate employability and employment opportunities with HE institutions. 


\section{References}

Agrawal, T. (2013) Skill Development in India: An Examination, Journal of Education and Work, DOI: 10.1080/13639080.2013.787485

Andrews, G. and Russell, M. (2012) Employability skills development: Strategy, evaluation and impact. Higher Education, Skills and Work-based Learning. 2 (1), 3344.

Armsby, P. and Costley, C. (2000) Research driven projects. In Work Based Learning and the University: New Perspectives and Practices, Portwood, D. and Costley, C. (Eds.). Birmingham: Staff and Educational Development Association

BIS (2011) Supporting Graduate Employability: HEls Practice in Other Countries, London: Crown Copyright, Available at: https://www.gov.uk/government/publications/supporting-graduate-employabilitypractice-in-other-countries (Accessed 21 October 2013)

Bothwell, E. (2016) Integrate employability and internationalisation, universities told. Times Higher Education. Available at: https://www.timeshighereducation.com/news/integrate-employability-andinternationalisation-universities-told (Accessed 13 January 2017)

Bowers-Brown, T., \& Harvey, L. (2004). Are there too many graduates in the UK? A literature review and an analysis of graduate employability. Industry and Higher Education, 18(4), 243-254.

Boyatzis, R. E. (1998). Transforming qualitative information: Thematic analysis and code development. Sage.

Brown, M. (2014) Higher Education as a Tool of Social Mobility: Reforming the Delivery of HE and Measuring Professional Graduate Output Success, London: Centre Forum

Browne, J. (2010), "Securing a sustainable future for higher education", an independent review of

higher education funding and student finance, available at: www.independent.gov.uk/ browne-report (accessed 18 October 2010).

Bryson, J. (2013) Putting Skill in its Place, Journal of Education and Work, DOI: 10.1080/13639080.2013.835794

Butcher, V., Smith, J., Kettle, J. and Burton, L. (2011) Review of Good Practice in Employability and Enterprise Development by Centres for Excellence in Teaching and Learning. York: Higher Education Academy

CBI (2009) Stronger Together: Businesses and Universities in Turbulent Times, London: $\mathrm{CBI}$ 
CBI (2011) Building for Growth: Business Priorities for Education and Skills, Available http://www.cbi.org.uk/media/1051530/cbi_edi_education__skills_survey_2011.pdf (Accessed 21 October 2013)

Cranmer, S. (2006) Enhancing graduate employability: best intentions and mixed outcomes. Studies in Higher Education, 31, pp.169-84.

Dearing, R. (1997) The Dearing Report: Report for the National Committee of Inquiry into Higher Education: Higher Education in the Learning Society, London: HMSO.

Docherty, D. (2013) Introducing the National Centre for Universities and Businesses, HESCU: Graduate Market Trends, Available at: http://www.hecsu.ac.uk/assets/assets/documents/GMT_summer_2013.pdf (Accessed 23 October 2013)

Felstead, A., Gallie, D., Green, F. and Inanc, H. (2013) Skills At Work In Britain: First Findings from the Skills and Employment Survey 2012, London: Centre for Learning and Life Chances in Knowledge Economies and Societies, Institute of Education.

Haasler, S. R. (2013) Employability Skills and the Notion of 'Self', International Journal of Training and Development 17 (3), 233-243. Available at: http://onlinelibrary.wiley.com/doi/10.1111/ijtd.12012/pdf (Accessed 19 October 2013)

Harvey, L., and Knight, P. (2003) Briefings on Employability 5: Helping Departments to Develop Employability, York: ESECT

Harvey, L., Locke, W., \& Morey, A. (2002). Enhancing Employability, Recognising Diversity. London Universities: UK

HESA (2013) Destination of Leavers from Higher Education: Survey 2013 Summary Report, London: Higher Education Statistics Agency

HESA (2014) Statistical First Release 197: Student Enrolments and Qualifications. Available at: https://www.hesa.ac.uk/sfr197 (Accessed 5 August 2014)

Hesketh, A. (2003) Employability in the Knowledge Economy: Living the Fulfilled Life or Policy Chimera?, Lancaster: Lancaster University Management School

Holmes, L. (2013) Competing perspectives on graduate employability: possession, position or process?, Studies in Higher Education, 38 (4), 538-554 Available at: http://dx.doi.org/10.1080/03075079.2011.587140 (Accessed 20 October 2013)

James, A. (2008) Personal and Professional Development (PPD): Learning for Life, London: University of the Arts London

Knight, P. T. and Yorke, M. (2003) Employability and Good Learning in Higher Education, Teaching in Higher Education, 8:1, pp.3-16 
Lambert, R. (2003) Lambert Review of Business-University Collaboration Final Report, London: HM Treasury.

Lees, D. (2002). Graduate employability-literature review (pp. 1-23). LTSN Generic Centre.

Leitch, S. (2006) Prosperity for All in the Global Economy - World Class Skills. Final report of the Leitch Review of Skills (London: HMSO/HM Treasury).

Lester, S. and Costley, C. (2010) Work-Based Learning at Higher Education Level: Value, Practice and Critique, Studies in Higher Education, 35 (5), pp.561-575

Lowden, K., Hall, S., Elliot, D. and Lewin, J. (2011) Employers' Perceptions of the Employability of New Graduates. London: Edge Foundation. Available from: http://www.edge.co.uk/media/63412/employability_skills_as_pdf__final_online_version.pdf (Accessed 17 October 2013)

Maxwell, G., Scott, B., Macfarlane, C. and Williamson, E. (2009) Employers as Stakeholders in Postgraduate Employability Skills Development, International Journal of Management Education, 8 (2), pp.1-11.

Miller, L., Biggart, A. and Newton, B. (2013), Basic and employability skills. International Journal of Training and Development, 17: 173-175. Available at: http://onlinelibrary.wiley.com/doi/10.1111/ijtd.12007/pdf (Accessed 18 October 2013)

Mina, A. and Probert, J. (2012) Enhancing Collaboration Creating Value: Business Interaction with the UK Research Base in Four Sectors. London: Council for Industry and Higher Education

Morrison, A. R. (2014) 'You Have To Be Well Spoken': Students' Views on Employability within the Graduate Labour Market, Journal of Education and Work, DOI: $10.1080 / 13639080.2012 .742178$

NCUB (2015) National Centre for Universities and Businesses: Members, Available at: http://www.ncub.co.uk/members-search.html (Accessed 8 February 2015)

Pegg, A., Waldock, J, Hendy-Issac, S. and Lawton, R. (2012) Pedagogy For Employability. York: Higher Education Academy.

Rae, D. (2008) Riding Out the Storm: Graduates, Enterprise and Careers in Turbulent Economic Times. Education and Training, 50, pp.748-763.

Sear, L. (2012) Graduate Recruitment to SMEs: Final Report, Aycliffe: SFEDI, BIS

Stott, T., Zaitseva, E. and Cui, V. (2012) Stepping back to move forward? Exploring Outdoor Education students' fresher and graduate identities and their impact on employment destinations, Studies in Higher Education, Available at: http://www.tandfonline.com/doi/pdf/10.1080/03075079.2012.743116 (Accessed 4 November 2013) 
Tibby, M. (2012) Employer and Student Perspectives on Employability, York: Higher Education Academy, Available at: http://www.agcas.org.uk/assets/download?file=3630\&parent=1399 (Accessed 21 October 2013)

Tobin, L. (2010) Students Look to Extra-Curricular Activities to Give Them Employability, Guardian Higher Education, Available at: http://www.theguardian.com/education/2010/apr/20/student-employability-extracurricular-skills (Accessed 14 April 2014)

Tomlinson, M. (2007) Graduate employability and student attitudes and orientation to the job market, Journal of Education and Work, 20 (4), pp.285-304.

Tomlinson, M. (2012). Graduate employability: A review of conceptual and empirical themes. Higher Education Policy, 25(4), 407-431.

Tongco, M. D. C. (2007). Purposive sampling as a tool for informant selection. Available at: https://scholarspace.manoa.hawaii.edu/bitstream/handle/10125/227//1547-3465-05147.pdf (Accessed 2 January 2017).

Universities UK (2013a) The Funding Environment for Universities: An Assessment, London: Universities UK

Universities UK (2013b) Patterns and Trends in UK Higher Education, Available at: http://www.universitiesuk.ac.uk/highereducation/Documents/2013/PatternsAndTrend sinUKHigherEducation2013.pdf (Accessed 7 December 2013)

Wilson, T. (2012) A Review of Business-University Collaboration. London: Department of Business Innovation and Skills. Available at: http://www.wilsonreview.co.uk/wilson-review/wilson-review.pdf (Accessed: 21 October 2013)

Witty, A. (2013) Encouraging a British Invention Revolution: Sir Andrew Witty's Review of Universities and Growth, London: Crown Copyright, Available at: https://www.gov.uk/government/uploads/system/uploads/attachment_data/file/24972 0/bis-13-1241-encouraging-a-british-invention-revolution-andrew-witty-review-R1.pdf (Accessed 21 October 2013)

Yorke, M. (2004) Employability and higher education: What it is - And what it is not. York, UK:Higher Education Academy.

Yorke, M., and Knight, P. (2006). Embedding employability into the curriculum. In "Learning and Employability." (M. Yorke, Ed.). 24. Learning and Teaching Support Network (LTSN) (Higher Education Authority), York. 
